CHAPTER III

REPORT OF THE EXECUTIVE COMMITTEE

$\underline{1982-1984}$

\title{
President :
}

Prof. R. Hanbury Brown, School of Physics, University of Sidney, Sidney, NSW 2006, Australia.

Vice-Presidents :

Dr. M.W. Feast, South African Astronomical Observatory, P.O. Box 9, Observatory, Cape 7935, South Africa.

Prof. R.P. Kraft, Lick Observatory, University of Cali fornia, Santa Cruz, CA 95064, USA.

Dr. L. Kresak, Slovak Academy of Sciences, Dubravska Cesta 5, 84228 Bratislava, Czechoslovakia.

Prof. M. Peimbert, Instituto de Astronomia, Apartado Postal 70264, Mexico 04510 DF, Mexico.

Prof. R. Wilson Department of Physics and Astronomy, University College London, Gower Street, London WCIE 6BT, UK.

Prof. Ya. S. Yatskiv, Main Astronomical Observatory, Ukranian Academy of Sciences, SU$252127 \mathrm{Kiev}$, USSR.

\section{General Secretary :}

Dr. R.M. West, European Southern Observatory, Karl-Schwarzschild-Strasse 2, D-8046 Garching bei München, F.R. Germany.

\section{Assistant General Secretary :}

Dr. J.-P. Swings, Institut d'Astrophysique, 5 avenue de Cointe, B-4200 Cointe-Ougrée, Belgium.

\section{Adviser :}

Prof. P.A. Wayman, Dunsink Observatory, Dublin 15, Ireland.

\section{INTRODUCTION}

The present report covers the period from lst January 1982 to 31 December 1984. This period includes the first eight months (to 26 August) of 1982, which was part of the period in office of the previous Executive Committee ; it does not include the first eleven months of 1985, still the responsibility of the present Executive Committee (to 28 November 1985).

The address of the General Secretary at the XIXth General Assembly will include a report for the period 1st January-19 November 1985.

The report includes a summarized financial report for the calendar years 1982, 1983 and 1984 and a budget proposal for the calendar year 1985, during the 3-year budgetary period 1983-1985. 


\title{
II. ADMINISTRATION
}

\section{Executive Committee}

The Executive Committee held the following meetings :

49 th Meeting : Patras, Greece, 15, 16 and 24 August 1982.

50th Meeting : Patras, Greece, 26 August 1982.

51st Meeting : Munich, F.R. Germany, 12-15 September 1983.

52nd Meeting: Ile d'Yeu, France, 10-13 September 1384.

The 49 th and 50 th meetings were held in the shadow of the illness and subsequent death on 19 August 1982, of the President of the Union (1979-1982), Prof. M.K.V. Bappu. The participants in the the XVIIIth General Assembly paid a moving tribute to the mernory of Prof. Bappu on 23 August 1982, cf. IAU Transactions XVIIIB, page 1.

In the absence of the President, the 49 th Meeting was chaired by Vice-President, Dr. D.S. Heeschen; all other members were present. Prof. R. Hanbury Brown, President-elect, and Dr. J.-P. Swings, Assistant General Secretary elect, participated also in this meeting.

The 50th, 51st and 52nd meetings were held under the chairmanship of Prof. R. Hanbury Brown, President of the IAU. All other members participated. It was decided that the position as adviser to the Executive Committee, which is normally taken by the Past President during the three years after a General Assembly, would remain unfilled after Prof. Bappu's death.

\section{Officers' Meetings} follows :

The President, the General Secretary and the Assistant General Secretary met as

Patras, Greece, 17-18 February 1982

Munich, F.R. Germany, 11 September 1983

Patras, Greece, 14 August 1982

Delhi, India, 22-24 January 1984

Paris, France, 20 January 1983

Paris, France, 9 September 1984

\section{IAU Secretariat}

The IAU Secretariat continued to function at its permanent seat in Paris according to an agreement signed with the Paris Observatory on 7 December 1981 ; the address is :

\author{
I A U - U A I \\ 6l, avenue de l'Observatoire \\ F-75014 Paris \\ Telephone : 33 (1) 43-25-83-58 Telex : 205671 IAU F
}

A Xerox 860 word processor was acquired in November 1982 and a Canon NP 120 photocopier in April 1983. The telex connection was installed in May 1983. For the IAU computerized member file, an IBM XT minicomputer with a 10 Mbyte hard disc and an ink-jet printer was acquired in December 1984. Various minor improvernents (e.g. floor, furniture) were made.

\section{IAU Staff}

Mrs. B. Manning continued as IAU Secretary. Ms. P. Smiley, Typist, left in November 1983. Miss D. Lours was employed as IAU Assistant Secretary from 15 March 1984. 


\section{Adhering Countries}

Chinese membership of IAU was ratified by the XVIIIth General Assembly (Resolution Al ; cf. Transactions XVIII B, page 25).

\section{Members of the IAU}

There were about 4497 members on 1 January 1982. 795 new members were elected at the XVIIIth General Assembly. 91 names were deleted by resignation and decease up to December 1982. Since that date there have been recorded 55 further names for deletion. The number of members at 31 December 1984 is therefore estimated to be around 5146 . The approximate numbers of IAU members, residing within the geographical areas of IAU Adhering Bodies, are indicated in Section VIII of this report. In addition, IAU members reside in Libya (1), Nigeria (2), Lebanon (1), Philippines (1), Saudi Arabia (2), Singapore (2), Trinidad and Tobago (I).

\section{Consultants to IAU Commissions} 1982.

The 40 IAU Commissions had a total of approximately 188 consultants at 31 Decernber

\section{COMMISSIONS OF THE IAU}

By resolution of the XVIIIth General Assembly, Commission 51 "Search for Extraterrestrial Life" was created. The names of Commission 26 and 34 were changed to "Double and Multiple Stars" and "Interstellar Matter", respectively.

Commission Reports, covering the period 1 July 1981 - 30 June 1984 have been published in early 1985 (IAU Transactions Vol. XIX A, 725 pages).

The following remarks concern some of the many Commission activities not otherwise included in subsequent sections of this report :

Commission 5: Work continued on the new IAU Style Book, which is expected to be ready before the XIXth General Assembly.

Commission 6 : The IAU Central Bureau for Astronomical Telegrams (Director : Dr. B.G. Marsden) issued 369 Circulars and 170 "Telegram Books" in this period.

Commission 15 : The XVIIIth General Assembly decided to support the International Halley Watch (IHW) as coordinating authority for observations of Comet P/Halley during its $1985-86$ return.

Commissions 19 and 31 : The MERIT Main Campaign took place from 1 September 1983 31 October 1984. Reports about the work of the MERIT and CUTES groups appeared in successive issues of the Information Bulletin (e.g. 53, pp. 16-17).

Commission 20 : Together with Commission 6 and the IAU Working Group for Planetary Syste:n Nomenclature (WGPSN), procedures were established for assigning names and designations to various classes of newly-discovered bodies in the solar system. The IAU Minor Planet Center (Director : Dr. B.G. Marsden) issued more than 2600 MPC's and numbered no less than 642 new minor planets during 1982-84.

Commission 22 : An IAU Meteor Data Center was created in Lund, Sweden, under the directorship of Prof. B.A. Lindblad. 
Commission 38 : Under the guidance of its President, Prof. F.B. Wood, this Commission continued to give assistance to (young) astronomers under agreed rules (cf. IB 50, pp. 1113).

Commission 46 : The Visiting Lecturers' Programme Subcommittee (Chairman : Prof. D.G. Wentzel) decided to recommend that the VLP's be initiated in Lima, Peru and Nsukka, Nigeria.

\section{SCIENTIFIC MEETINGS}

\section{Symposia and Colloquia}

The following IAU meetings were held :

IAU Symposium No. 101 : "Supernovae Remnants and their X-ray Emission", Venice, Italy, 30 August - 2 September 1982.

IAU Symposium No. 104 : "The Early Evolution of the Universe and its Present Structure", Kolymbari, Crete, Greece, 30 August - 2 September 1982.

IAU Symposium No. 105 : "Observational Tests of the Stellar Evolution Theory", Geneva, Switzerland, 12-16 September 1983.

IAU Symposium No. 106 : "The Milky Way Galaxy", Groningen, Netherlands, 30 May - 3 June 1983.

IAU Symposium No. 107 : "Unstable Current Systems and Plasma Instabilities in Astrophysics", College Park, MD, USA, 8-11 August 1983.

IAU Symposium No. 108 : "Structure and Evolution of the Magellanic Clouds", Tübingen, FRG, 5-8 September 1983.

IAU Symposium No. 109 : "Astrometric Techniques", University of Florida, USA, 9-12 January 1984.

IAU Symposium No. 110 : "VLBI and Compact Radio Sources", Bologna, Italy, 27 June - 1 July 1983.

IAU Symposium No. 111 : "Calibration of Fundamental Stellar Quantities", Como, Italy, 2429 May 1984.

IAU Symposium No. 112 : "The Search for Extraterrestrial Life : Recent Developments", Boston, USA, 18-21 June 1984.

IAU Symposium No. 113 : "Dynamics of Star Clusters", Princeton, USA, 29 May - 1 June 1984.

IAU Colloquium No. 73 : "Ultraviolet and X-ray Spectroscopy of Astrophysical and Laboratory Plasmas", Dublin, Ireland, 30 August - 1 September 1982.

IAU Colloquium No.74 : "Dynamical Trapping and Evolution in the Solar System", Chalkidiki, Greece, 30 August - 2 September 1982.

IAU Colloquium No. 75 : "Planetary Rings", Toulouse, France, 30 August - 2 September 1982.

IAU Colloquium No. 76 : "The Nearby Stars and the Stellar Luminosity Function", Middletown, CT, USA, 12-13 June 1983.

IAU Colloquium No. 77 : "Natural Satellites", New York, USA, 5-9 July 1983.

IAU Colloquium No. 78 : "Astronomy with Schmidt-type Telescopes", Asiago, Italy, 30 August - 2 September 1983. 
IAU Colloquium No. 79 : "Very Large Telescopes, their Instrumentation and Programs", Garching bei München, F.R. Germany, 9-12 April 1984.

IAU Colloquium No. 80 : "Double Stars - Physical Properties and Generic Relations", Bandung, Indonesia, June 3-7, 1983.

IAU Colloquium No. 81 : "Local Interstellar Medium", Madison, WI, USA, 4-6 June 1984.

IAU Colloquium No. 82 : "Cepheids : Theory and Observations", Toronto, Canada, 28 May 1 June 1984.

IAU Colloquium No. 83 : "Dynamics of Comets : Their Origin and Evolution", Rome, Italy, 11-14 June 1984.

IAU Colloquium No. 84 : "Longitude Zero", Greenwich, UK, 9-13 July 1984.

IAU Colloquium No. 85 : "Properties and Interactions of Interplanetary Dust", Marseille, France, 9-12 July 1984.

IAU Colloquium No. 86 : "Eighth International Colloquium on Ultraviolet and $X$-ray Spectroscopy of Astrophysical and Laboratory Plasmas", Washington, USA, 27-29 August 1984.

\section{Cosponsored Meetings}

IAU cosponsored the following meetings :

COSPAR/IAU Symposium on "Gamma-Ray Astronomy in Perspective of Future Space Experiments", Ottawa, Canada, 18-19 May 1982.

COSPAR/IAU/IAMAP/IUTAM/URSI Symposium on "Giant Planets and their Satellites", Ottawa, Canada, 18-21 May 1982.

COSPAR/IAU Symposium on "Advanced Space Instrumentation in Astronomy", Ottawa, Canada, 20-22 May 1982.

COSPAR/IUTAM/IAU/IUGS Symposium on "Impact Processes of Solid Bodies", Ottawa, Canada, 21 -22 May 1982.

COSPAR/IAU/SCOSTEP Symposium on the "Solar Maximum Year", Ottawa, Canada, 25-27 May 1982.

IUPAP/IAU "International Conference on Plasma Physics", Gothenburg, Sweden, 9-15 June 1982.

EPS/IAU : "Fourth CESRA Workshop on Solar Noise Storms", Trieste, Italy, 9-13 August 1982.

IAIJ/UN International Seminar on Astronomy (at the time of UNISPACE 82), Vienna, Austria, 12 August 1982.

COSPAR/IAU Symposium on "Advances of High Energy Astrophysics and Cosmology", Pamporovo, Bulgaria, 18-22 July 1983.

URSI/IAU Symposium "Measurement and Processing for Indirect Imaging", Sydney, Australia, 30 August - 3 September 1983.

COSPAR/IAU Symposium on "High Energy Astrophysical Sources", August 1983.

COSPAR/IAU Workshop on "Venus International Reference Atmosphere", Harnburg, FRG, 2425 August 1983.

IUGG/IAU Symposium on "Cosmic Dust in Planetary Atmosphere", Hamburg, FRG, 17 August 1983.

URSI/IAU Workshop on "Solar Terrestrial Prediction", Meudon, France, 18-22 June 1984. 
SCOSTEP/IAU Symposiun on "Solar Maximum Analysis", Graz, Austria, 25-27 June 1984.

COSPAR/IAU Symposium on "Planetology of Venus, Mars, and Satellites of Outer Planets", Graz, Austria, 26-28 June 1984.

COSPAR/IAU Symposium on "Nucleosynthesis and Acceleration of Cosmic Rays", Graz, Austria, 27-30 June 1984.

COSPAR/IAU Workshop on "Venus Atmosphere", Graz, Austria, 25-30 June 1984.

\section{Regional Meetings}

Third Latin-American Regional Astronomy Meeting, Buenos Aires, Argentina, 28 November 3 December 1983.

Seventh European Regional Astronomy Meeting, Florence, Italy, 12-16 December 1983.

Eighth European Regional Meeting, Toulouse, France, 17-21 September 1984.

Third Asian-Pacific Regional Astronomy Meeting, Kyoto, Japan, I-5 October 1984.

Fourth Latin-American Regional Astronomy Meeting, Rio de Janeiro, Brazil, 19-24 November 1984.

\section{IAU/UNESCO Young Astronomers' Schools}

IAU Commission 46 "Teaching of Astronomy" organized the XIIIth School at Lembang, Indonesia, 16 May - 2 June 1983. It brought together 21 students from India, Indonesia, Malaysia, Philippines and Thailand. The curriculum included Solar Physics and Galactic Structure.

\section{XVIIIth General Assembly, Patras, Greece, 17-26 August 1982}

IAU Transactions, Volume XVIIIB (1983), contains a report of the Proceedings of the General Assembly of the Union, including the resolutions passed at the Assembly. It also contains the reports of Commission meetings during the period of the General Assembly.

The IAU Statutes, By-laws and Working Rules, as updated at the XVIIIth General Assembly, are also included in Vol. XVIIIB, page $397 \mathrm{ff}$.

\section{PUBLICATIONS}

\section{Publisher}

In November 1984, the contract with D. Reidel Publishing Co. was renewed for a six-year period, from 1985-1991.

\section{Sales} 1984.

Number of copies sold (hard,soft) by D. Reidel Publishing Company in the period 1982-

Transactions : XIIIA (4), XIIIB (2I), XIVA (8), XIVB (5), XVA (7), XVB (4), XVIA (3), XVIB (6), XVIIA part 1 (22), XVIIA part 2 (21), XVIIA part 3 (23), XVIIB (90), XVIIIA (493), XVIIIB (517).

Highlights : I (8), II (15), III (18), IV I (13, 5), IV 2 (10, 3), V (40, 55), VI $(335,188)$ 
Symposia Proceedings : 32 (17), 33 (0), 34 (32), 35 (22), $36(0), 37$ (7), 38 (44), 39 (26), 40 (18), $41(1), 42(17), 43(26), 44(39), 45(32), 46(33), 47(15), 48(32), 49(17,56), 50(12$, 38), $51(7,58), 52(14,57), 53(14,37), 54(15,34), 55(12,27), 56(4,4), 57(8,30), 58(6$, 53), $59(17,54), 60(13,36), 61(8,25), 62(8,36), 63(22,68), 64(18,48), 65(2,15), 66$ $(15,54), 67(28,74), 68(19,32), 69(15,35), 70(7,6), 71(10,10),(11,29), 80(7,25), 81$ $(37,23), 82(24,27), 83(11,18), 84(59,71), 85(38,77), 86(44,25), 87(62,144), 88(34$, 45), $89(23,14), 90(35,26), 91(41,32), 92(51,82), 93(82,115), 94(116,86), 95(108$, 1.10), 96 (76, 115), $97(473,424), 98(323,195), 99(384,224), 100(443,344), 101(403$, 230), $102(377,209), 103(390,252), 104(385,221), 105(342,154), 107(110,37), 108(359$, 131), $110(344,268)$.

\section{Information Bulletin}

Starting with issue No. 49 (January 1983), the IAU Information Bulletin was prepared and composed on the Xerox 860 Word Processor by the IAU Secretariat, and printed and distributed by Reidel. It appeared twice a year and was sent, free of charge, to IAU members, consultants, scientific institutions, and selected international organizations. Each print-run was 6300 copies.

\section{RELATIONS TO OTHER ORGANIZATIONS}

IAU was represented by the General Secretary at the following meetings of the International Council of Scientific Unions (ICSU) : 15/16th Meetings of the General Committee and 19th General Assembly (Cambridge, UK, September 1982); 17th Meeting of the General Committee (Warsaw, Poland, August 1983) ; 18/19th Meetings of General Committee and 20th General Assembly (Ottawa, Canada, September 1984). The IAU General Secretary was elected Ordinary Member of the ICSU Executive Board (1982-1986).

IAU was also represented at meetings of the ICSU Committee for Space Research (COSPAR) : XXIVth Plenary Meeting (Ottawa, Canada, May 1982) - P.A. Wayman and R.M. West ; XXVth Plenary Meeting (Graz, Austria, June-July 1984) - R.M. West, L. Kresak and R. Wilson.

The following IAU Representatives to other ICSU and international bodies were active during the period 1982-84:

CCDS Consultative Comm. for the Definition of the Second

CCDM Consultative Comm. for the Definition of the Metre

CCIR

$$
\text { International Radio Consultative Committee }
$$

Study Group 2

Study Group 7

CCMP Coordination Committee for Moon and Planets

CODATA Committee on Data for Science and Technology

COSTED Comm. on Science and Technology in Developing Countries

CTS

EPS
Committee on the Teaching of Science

European Physical Society - Conference Committee
W. Markowitz

J. Benavente

A.H. Cook

J. Whiteoak

L.H. Doherty

H.M. Smith

J. Pilkington

P.M. Millman

M. Ya. Marov

B. Hauck

G. Swarup

D. McNally

J.-P. Swings 


$\begin{array}{lll}\text { FAGS } & \text { Federation of Astronomical \& Geophysical Services } & \text { E. Tandberg-Hanssen } \\ \text { - BIH } & \text { Bureau International de l'Heure } & \text { S. Iijima } \\ \text { - IPMS } & \text { International Polar Motion Service } & \text { Paquet } \\ \text { - IUWD } & \text { International Ursigram \& World Day Services } & \text { B. Kolaczek } \\ \text { - QBSA } & \text { Quarterly Bulletin on Solar Activity } & \text { H. Coffey } \\ \text { IAF } & \text { International Astronautical Federation } & \text { F. Moriyama } \\ \text { ICSTI } & \text { International Council for Scientific \& Technical Information W. Heintz } \\ & & \text { G. A. Wilkins } \\ \text { IUAA } & \text { International Union of Amateur Astronomers } & \text { J.-P. Swings } \\ & & \text { M. Rigutti } \\ \text { IUCAF } & \text { Inter-Union Commission on Frequency Allocation for } & \text { R. Schilizzi } \\ & \text { Radio Astronomy and Space Science } & \text { G. Swarup } \\ \text { IUCS } & \text { Inter-Union Commission on Spectroscopy } & \text { B. Edlen } \\ & & \text { J.G. Phillips } \\ \text { SCOPE } & \text { Scientific Committee on Problerns of Environment } & \text { M.J. Seaton } \\ \text { SCOSTEP } & \text { Scientific Committee on Solar-Terrestrial Physics } & \text { F.G. Smith } \\ \text { CCMP was discontinued in 1984. } & \text { M.R. Kundu }\end{array}$

UNESCO was regularly kept informed about relevant IAU activities. The IAU/UNESCO GERT project was delayed due to the necessity of a technical revaluation. A site in Surnatra, Indonesia, was found and a geological study was made.

A joint IAU/UN International Astronomy Seminar was held on 12 August, 1982 in Vienna, Austria at the time of the UNISPACE 82 Conference.

\section{FINANCIAL MATTERS}

\section{Summarized Account of Receipts and Payments for the 3-year Period 1982-84}

The 3-year summarized account shown in Table I, has been certified by the IAU Auditor, R. Bacle, H.E.C., Paris. The certified "Vérification des Comptes" for 1982, 1983 and 1984 will be available for examination by the Finance Committee of the XIXth General Assembly. 


\section{Balance 1982-1984}

$$
\text { Swiss Francs }
$$

Bank Balance : 31.12.1981

Re/Devaluation :

1982

1983

1984
Swiss Francs

663991.14

$+28442.98$
Result (Income - Expenditure)
1982

1983

1984

$\begin{array}{r}-6804.27 \\ +\quad 29133.05 \\ +111380.14 \\ \hline\end{array}$

Bank Balance : 31.12.1984

\section{Comments to Account and Balance 1982-84} were :

The ICSU mean conversion rates to Swiss Francs for the years 1982, 1983 and 1984

$\begin{array}{llllc} & \underline{1 U S \$} & \underline{1 D F 1} & \underline{1 F F} & \underline{1 D M} \\ 1982 & 2.0125 & 0.7589 & 0.31025 & \ldots \\ 1983 & 2.0858 & 0.7421 & 0.2784 & 0.8288 \\ 1984 & 2.3275 & 0.7342 & 0.2692 & 0.8263\end{array}$

The gains on transfers arise because of the difference between the conversion rate at the time of a transfer from one currency to another, and the above yearly mean rates used for establishment of the annual and 3-year accounts.

The re/devaluation figures represent the difference in the bank balances on 31.12. and on 1.1. as expressed in Swiss F rancs; e.g. the conversion from other currencies to Swiss Francs on 31.12 .82 is done according to the mean conversion rate of 1982 , and on 1.1 .1983 according to the mean conversion rate of 1983.

As was the case for the (1979-81) accounts, no distinction is made between "Savings" and "Current" accounts.

\section{Income}

ad 1 The XVIIIth General Assembly (1982) decided to increase the annual unit of contribution to 1760 Swiss Francs. Two countries, India and South Africa, asked to enter a higher category, so that the total number of units were 229 from 1982. Since 1982, some Adhering Organizations have paid their annual dues in advance. On 1.6.1985, eight Adhering Organizations were in arrears (up to and including 1984 dues) with a total of 26 units.

ad 2 Rnyalties from Reidel. A new six-year contract (1986-1991), signed in November 1984, guarantees the IAU a minimum of $75000 \mathrm{DF}^{-1} \mathrm{I}$ year in royalties. 
ad 3 When calculated straightforward from the interest and the mean of the opening (1.1.) and closing (31.12) balances, the mean interest rates were $6.36 \%$ (1982), $6.39 \%$ (1983 and $5.34 \%$ (1984), reflecting the 1984 drop in interest rates, mainly on US \$ accounts. B) currency, the IAU money was held as follows (in percent):

$\begin{array}{lllll} & \text { SFr } & \text { US\$ } & \text { FF } & \text { DFI } \\ 31.12 .1981 & 33.2 & 41.1 & 5.9 & 19.8 \\ 31.12 .1982 & 30.9 & 41.9 & 7.9 & 19.3 \\ 31.12 .1983 & 41.2 & 41.4 & 1.2 & 16.2 \\ 31.12 .1984 & 37.0 & 47.3 & 0.8 & 14.9\end{array}$

By cash-flow managernent, a minimum of money (normally about $15 \%$ ) was held in current, low-interest accounts.

ad 4 A basic allocation and support for specific projects was received from ICSU (UNF-SCO subvention or ICSU grant) as follows (in US\$) :

$$
1982 \quad 1983 \quad 1984 \quad(1982-1984)
$$

$\begin{array}{lrrrrr} & 1982 & 1983 & 1984 & (1982-1984) \\ \text { Basic allocation } & 13991 & 13495 & 12634 & 40120 \\ \text { Project MERIT } & & 4000 & 5000 & 9000 \\ \text { Commission 38 Travel Grants } & & 3000 & 3000 & 6000 \\ \text { IAU VLP } & 4000 & -- & 4000 & 4000 \\ \text { IAU ISYA TOTAL } & 17991 & \frac{--}{20495} & \frac{-}{24634} & \frac{4000}{63120}\end{array}$

ad 5 Includes FF 45 000.- from Ministère des Relations Extérieures (Paris) in support of the $\overline{52}$ nd Executive Cominittee Meeting (Ile d'Yeu, France), which is herewith gratefully acknowledged.

\section{Expenditure}

ad 1 Including equipment (Xerox 860 Word Processor, Canon Photocopier, telex machine and IBM XT 256 computer), charges for building to Paris Observatory (electricity, heating, overheads), operation costs (stationery, postal charges, etc.), salaries and social charges for the IAU Secretary and Assistant Secretary, General Serretary expenses (travel and subsistence) and Audit Fees. Major contributions to the functioning of IAU were made by the home institution of the General Secretary (ESO, Garching) and Assistant General Secretary (Institut d'Astrophysique, Liège) in the form of administrative assistance. The Assistant General Secretary was also supported by grants from the Belgian Ministry of Education.

ad 2 Contribution to ICSU is $2.5 \%$ of the contribution from Adhering Organizations during the preceding year.

ad 3 Includes payment of the ICSU contributions to Project MERIT (to BIH and in support of MERIT meetings) and IAU support to Meteor Data Center, as decided by the XVIIIth General Assembly, and for which no provisions were made in the adopted (1983-85) budget.

ad 4 Details in Table II. Note that the extra 10000 Swiss Francs, allocated to Commission 38 (cf. IB 48, p. 39) were not used. Due to delays in the implementation of the 
Lima and Nsukka VLP's, spending only started in 1984. The Commission 27 money, which is handled within the IAU accounts, was drawn upon in 1982 in connection with the General Assembly. This sum was erroneously debited to Item 5. On 31.12.84, the credit to Commission 27 was 11548.03 Swiss Francs.

ad 5 Details about the spending in 1982 will be found in the "Vérification des Comptes 1982". The additional amount paid in 1983 to the Local Organizing Committee in Patras was authorized by the Executive Committee during its 51 st meeting (1983).

ad 6 Each issue of the Information Bulletin was printed in 6300 copies. The cost in Dutch Guilders, including postage which depends on the number of pages was : IB 47 (9 694.88); IB 48 (12 381.70) ; IB 49 (19 616.00, including covers for IB 49-54); IB 50 (11 067.00) ; IB 51 (13 410.35) and IB 52 (12 240.25). Due to increasing postage rates in the Netherlands, it was decided to make use of "air-speeded" mail-service to North America.

ad 7 The costs were significantly reduced by distributing soft-cover copies only. Some institutes were added to the distribution list.

ad 8 The added transportation cost to the 52nd meeting was covered by a grant (see above). The Executive Committee acknowledges with gratitude the hospitality offered by ESO (1983) and by Prof. J.-C. Pecker and the lle d'Yeu authorities (1984).

ad 9 Comparatively large expense in 1984 because of the Officers' Meeting in Delhi, as part of preparations for General Assembly in 1985.

ad 10 In support of 30 IAU-sponsored and 18 co-sponsored meetings (cf. Section IV I) :

$$
\text { Symposia Colloquia Co-Sponsored Meetings }
$$

$\begin{array}{llll}1982 & 5 & 5 & 8 \\ 1983 & 5 & 4 & 5 \\ 1984 & 4 & 7 & 5\end{array}$

ad 11 Contribution to CTS (US $\$ 400$ per year), FAGS (SFr 2000 in 1982, US $\$ 2000$ in 1983 and 1984), ICSTI (US\$ 360 per year), IUCAF (US\$ 1250 per year), and SCOSTEP (US\$ 1. 000 in 1982).

ad 12 "First Dictionary of the Nomenclature of Celestial Objects" (delayed from 1982 ; SFr $1 \overline{148}$ paid in 1983); Working Group on Photographic Problems (SF 1384.95 in 1984); AAVSO Publication (SF r 6000 in 1984).

ad 13 Part of cost of IAU Representation to meetings of FAGS, CCIR, IAF, ICSTI, EPS, COSPAR, SCOSTEP, SCOPE, COSTED and URSI.

ad 15 Late payments for 1980 Hvar School (US\$110) and 1981 Cairo School (US\$ 1250 ) in 1982. Payment to Bandung School in 1983. No School in 1984.

ad 16 Extra travel support to Kyoto (1984) meeting, since this was the first major IAUsponsored ineeting with participants from P.R. China.

ad 17 No SNC meetings were held. Communication costs only.

ad 18 Including Swiss anticipated tax (35\% of interest on current accounts in SF $r$ ) and NRA on US\$-account in 1983 (the type of account was changed and no NRA tax was paid in 1984). 


\section{Conclusion}

The total balance on 31.12.1984 was 162151.90 Swiss Francs higher than on 31.12.1981. As explained above, this $24 \%$ increase is mainly due to the increased SFr-value of US\$ holdings, following the revaluation of the US\$ against all other currencies in late 1984. Moreover, some Adhering Bodies paid their annual 1985 dues already in 1984 (altogether 32 units, i.e. SF r 56 320).

\section{Residual Budget for the year 1985 and Budget Proposal 1985}

The figures in the accounts for 1983 and 1984, added together for each itern, are subtracted from the figures for 1983-85, as approved by the General Assembly in 1982. In this way a Residual Budget 1985 is obtained. Negative figures mean that the 1983-85 Budget figure has been exceeded. Based upon careful examination of trends and figures actually achieved, the Executive Committee approved some changes during its 52nd Meeting in September 1984. Two sets of figures are given in Table III :

l. Residual Budget 1985, as explained above.

2. Budget Proposal 1985, to be referred to the Finance Committee at the XIXth General Assembly for presentation to the Assembly, according to IAt] Statute 18(b).

\section{Explanatory Notes to Budget Proposal 1985}

The changes proposed by the Executive Committee are explained as follows :

\section{Income}

ad 1 No change. Arrears and advance payments are expected to cancel out.

ad 2 Same level of royalties as in earlier years.

ad 3 Conservative estimate. More funds must be mobilized in low-interest accounts during a General Assembly year. Lower interest on US $\$$ accounts due to general fall in rates may be expected in 1985 .

ad 4 US $\$ 27$ 989.- was allocated by ICSU in September 1984 to IAU for transfer in 1985. However, the payment is dependent upon the receipt by ICSIJ, in mid-1985, of the foreseen UNESCO subvention. Hence the cautious figure.

\section{Expenditure}

ad 1 Same level of expenditure as in 1983 and 1984. Although no purchase of major equipment is planned, there are additional expenses in connection with the preparations for the General Assembly and the verification of the computerized membership file (postage, stationery).

\section{ad 2 Paid in April 1985.}

ad 3 Payment of ICSU 1985 contribution to MERIT and IAU contribution to Meteor Data Center, plus minor expenses. 
ad 4 Expenses now foreseen as follows:

\begin{tabular}{lllr} 
Item 4.1 & Commission 38 & Exchange of Astronomers & 25000 \\
Item 4.2 & Commission 46 & Visiting Lecturers'Programme & 12000 \\
& & Newsletter etc. & 1800 \\
Item 4.3 & Commission 6 & Telegram Bureau & 3100 \\
& Commission 20 & Minor Planet Center & 3100 \\
& Commission 27 & Variable Stars & 10000 \\
& & & 55000 \\
\hline
\end{tabular}

The Commission 38 Travel Grant Scheme is supplemented with funds received from IC.SU. Due to the late start, less funds are needed for the Lima and Nsukka VL_P's.

ad 5 SFr 30000 added. The reasons are the unforeseen payment in 1983 to the Patras L.OC and the wish of the $F_{-} C$ to help the largest possible number of IAU members to participate in the XIXth General Assembly.

ad 6 Information Bulletin Nos. 53 and 54. Free distribution to Commission Presidents of IAUTransactions Vol. XIX A (1985), purchased at a very reduced rate from Reidel for this purpose.

ad 7 A few institutes in developing countries have been added to the distribution list.

ad 8 No expenses in 1985.

ad 9 Meeting at Paris Secretariat in June 1985.

ad 10 SFr 25000 added in order to increase number of meetings around General Assembly which can be supported. For 1985, 7 Symposia and 4 Colloquia have been planned.

ad 11 SF $r 12000$ less than foreseen in (1983-85) budget.

ad 12 No major expenses expected in 1985.

ad 15 ISYA in Punjab (October - November 1985) was postponed.

ad 16 No Regional Astronomy Meeting in 1985.

ad 17 No expenses expected in 1985.

\section{LIST OF ADHERING ORGANIZATIONS}

(Not reproduced here, see p. 383).

\section{LIST OF DECEASED MEMBERS}

(See updated list on page 14). 


\section{LIST OF IAU PUBLICATIONS}

\section{Transactions and Highlights}

Transactions XVIIIA : (Patras, 1982) pp. viii + 669, D. Reidel Publishing Company, 1982.

Transactions XVIIIB : (Patras, 1982) pp. x +604, D. Reidel Publishing Company, 1983.

Highlights of Astronomy, Volume 6, as presented at the XVIIIth General Assembly of the IAU, 1982, pp. viii +818 , D. Reidel Publishing Company, 1983.

\section{IAU Symposia Volumes}

97 -Extragalactic Radio Sources, D.S. Heeschen \& C.M. Wade, pp. xviii + 490, Reidel, 1982.

98 -Be Stars, M. Jaschek \& H.G. Groth, pp. xvi + 523, Reidel, 1981.

99 -Wolf-Rayet Stars : Observations, Physics, Evolution, C.W.H. de Loore \& A.J. Willis, pp. $x x+618$, Reidel, 1982.

100 -Internal Kinematics \& Dynamics of Galaxies, E. Athanassoula, pp. xvi +432 , Reidel, 1982.

101 -Supernova Remnants and their X-Ray Emission, J. Danziger and P. Gorenstein, pp. xvii + 614, Reidel, 1983.

102 -Solar and Stellar Magnetic Fields: Origins and Coronal Effects, J.O. Stenflo, pp. $x+564$, Reidel, 1983 .

103 -Planetary Nebulae, D.R. Flower, pp. xxi + 554, Reidel, 1983.

104 -Early Evolution of the Universe and its Present Structure, G.O. Abell and G. Chincarini, pp. $\times x i+536$, Reidel, 1983 .

105 -Observational Tests of the Stellar Evolution Theory, A. Maeder and A. Renzini, pp. xxiv + 590, Reidel, 1984.

107 -Unstable Current Systems and Plasma Instabilities in Astrophysics, M.R. Kundu and G.D. Holman, pp. xxii + 566, Reidel, 1984 .

108 -Structure and Evolution of the Magellanic Clouds, S.van den Bergh and K.S. de Boer, pp. xvii + 425, Reidel, 1984.

110 -VLBI and Compact Radio Sources, R. Fanti, K. Kellermann, and G. Setti, pp. xx + 489, Reidel, 1984.

\section{IAU Colloquia Volumes}

$60-$ Uranus \& the Outer Planets, G. Hunt, Cambridge University Press, pp. ix + 307, 1982. 
61 -Comets, Gases, Ices, Grains \& Plasınas, L.l.. Wilkening, review papers will be published by the University of Arizona Press : "Comets", edited by J.P. Burns and contributed papers in Icarus, issue dedicated to comets.

62 -Current Techniques in Double \& Multiple Star Research, R.S. Harrington and O.G. Franz, Lowell Observatory Bulletin No. 167, vol. IXNo. 1, 1983, Lowell Observatory, PO Box 1269, Flagstaff, AZ 86002, USA.

63 -High-Precision Earth Rotation \& Earth-Moon Dynamics, D. Calame, Astrophysics \& Space Science Library 94, pp. 376, Reidel, 1982.

64 -Automated Data Retrieval in Astronomy, C. Jaschek \& W. D. Heintz, Astrophysics \& Space Science Library 97, pp. xx + 324, Reidel, 1982.

66 -Problems of Solar \& Stellar Oscillations, D.O. Gough, pp. 494, reprinted from "Solar Physics", vol. 82, Nos 1 and 2, Reidel, 1983.

67 -Instrumentation for Astronomy with Large Optical Telescopes, C. Humphries, Astrophysics \& Space Science Library, 92, pp. xvii + 321, Reidel, 1982.

68 -Astrophysical Parameters for Globular Clusters, A.G. Davis Philip, L. Davis Press, Inc., 1125 Oxford Place, Schenectady NY 12308, USA, pp. 630, 1982.

69 -Binary \& Multiple Stars as Tracers of Stellar Evolution, Z. Kopal \& J. Rahe, Astrophysics \& Space Science Library, 98, pp. xxx + 503, Reidel, 1982.

70 - The Nature of Symbiotic Stars, M. Friedjung \& R. Viotti, Astrophysics \& Space Science l.iibrary 95, pp. xix + 310, Reidel, 1982.

71 -Activity in Red-Dwarf Stars, P.B. Byrne \& M. Rodono, Astrophysics \& Space Science L_ibrary 102, xxvi + 669 pp., Reidel, 1983.

72 -Cataclysmic Variables and Related Objects, M. L_ivio \& G. Shaviv, Astrophysics ix Space Science L_ibrary 101, pp. xii + 351, Reidel, 1983.

73 -7th International Colloquium on Ultraviolet and $X$-ray Spectroscopy of Astrophysical and Laboratory Plasmas, no proceedings, but a limited number of ccpies of the Programme and Abstract booklet are available from Professor P.K. Carroll, Physics Dept, University College, Dublin, Ireland.

74 -Dynamical Trapping and Evolution in the Solar Systen, V.V. Markellos and Y. Kozai, Astrophysics \& Space Science Library 106, xvi + 424 pp., Reidel, 1983.

76 -The Nearby Stars and the Stellar Luminosity Function, A.G. Davis Philip and A. Upgren, Van Vleck Observatory Contribution No. 1, pp. xviii + 487, L. Davis Press, Inc., Schenectady, NY, USA, 1983.

78 -Astronomy with Schmidt-type Telescopes, M. Capaccioli, Astrophysics \& Space Science Library 110, pp. xii + 620, Reidel, 1984.

80 -Double Stars, Physical Properties and Generic Relations, B. Hidayat, Z. Kopal, and J. Rahe, reprinted from Astrophysics and Space Science 99, Nos. 1-2, pp. vi + 412, Reidel, 1984. 


\section{Proceedings of Regional Astronomy Meetings}

\section{Fifth European}

Liège, Belgium, 28 July - 1 August 1980,

Variability in Stars and Galaxies, P. Ledoux, xix $+456 \mathrm{pp} ., 1980$. Sold and distributed by :

Institut d'Astrophysique, avenue de Cointe 5, B-4200 Cointe-Ougrée, Belgium.

\section{Sixth European}

Dubrovnik, Yugoslavia, 19-23 October 1981,

Sun and Planetary System, W. Fricke and G. Teleki, xiii + 538 pp., Astrophysics \& Space Science Library 96, Reidel, 1982.

\section{Second Asian-Pacific}

Bandung, Indonesia, 24-29 August 1981,

M. Feast \& B. Hidayat, University Press, ITB, Bandung, Indonesia.

\section{Miscellaneous Publications}

Commission 5 : The First Dictionary of the Nomenclature of Celestial Objects. By A. Fernandez, M.C. Lortet and F. Spite, Astronomy \& Astrophysics Supplement,52, 4, June 1983.

Commission 6 : IAU (Telegram Bureau) Circulars. Issued by the IAU Central Bureau for Astronomical Telegrams, Smithsonian Astrophysical Observatory, 60 Garden Street, Cambridge, Massachusetts 02138, USA. Applications should be sent to B.G. Marsden at the above address.

Commission 10 : Cartes Synoptiques de la Chromosphère solaire et Catalngue des Filaments et des Centres d'Activité.

A complete list of the volumes of the "Cartes Synoptiques" which have been published may be obtained from the Observatoire de Paris, Section d'Astrophysique de Meudon, DASOP, 92190 Meudon, France.

Commission 10 : Quarterly Bulletin on Solar Activity.

Published at the Tokyo Astronomical Observatory, Attn. Dr. F. Moriyama, Mitaka, Tokyo 181, Japan.

Commission 10 : Sunspot Bulletin.

Published by the Sunspot Index Data Center (S.I.D.C.), Dr. André Koeckelenbergh, 3 Avenue Circulaire, B-1180 Bruxelles, Belgium.

Commission 19 : Circulaires du Bureau International de l'Heure.

A monthly publication of Bureau International de l'Heure, 61, Avenue de l'Observatoire, 75014 Paris, France.

Commission 19 : Monthly Notes of the International Polar Motion Service. Prepared and distributed by the Central Bureau of the International Polar Motion Service, International Latitude Observatory of Mizusawa-shi, Iwate-ken, Japan.

Commission 20 : Minor Planet Circulars.

Issued by the Minor Planet Center, Attn. Dr. B.G. Marsden, Center for Astrophysics, 60 Garden Street, Cambridge, MA 02138, U.S.A.

Commission 21 : Newsletter. 
Cormmission 26 : Circulaires d'Information de la Commission 26 (Double Stars).

Prepared and distributed by P. Couteau, Observatoire de Nice, B.P. 139, F-06003 Nice, France.

Commission 27 : Information Bulletin on Variable Stars.

Prepared and distributed by the Konkoly Observatory of the Hungarian Academy of Sciences, 1525 Budapest XII, Box 67, Hungary.

Cornmission 27 : General Catalogue of Variable Stars Catalogue of Suspected Variable Stars.

Name-lists of Variable Stars.

Distributed by Publishing House Nauka, Moscow, U.S.S.R.

Commission 29 : International Register of Stellar Spectroscopists, Edition 2, March 1982.

Edited by W.K. Bonsack, University of Hawaii and A. Slettebak, Ohio State University.

Commissions 29, 30 and 45 : Newsletter on Be Stars

Commission 41 : Newsletter.

Commission $\mathbf{4 2}$ : Standard Stars Newsletter

Commission 46 : Newsletter on the Teaching of Astronomy.

Commission 46 : Astronomy Education Materials.

Commission 51 : Newsletter.

IAU Information Bulletin Nos. 47 - 52.

MERIT Monthly Circular 1-15

MERIT Newsletter 1-6 


\section{Summary of Accounts 1982-1984 (Swiss Francs)}

\section{INCOME}

1. Contributions

2. Publications

3. [nterest

4. UNESCO/ICSU

5. Miscel1 aneous

Gain on Transfers

\begin{tabular}{|c|c|c|c|c|c|c|c|c|}
\hline & 1982 & & 1983 & & 1984 & \multicolumn{3}{|c|}{$1982-84$} \\
\hline 378 & 911.90 & 370 & 756.44 & 438 & 529.98 & 1 & 188 & 198.32 \\
\hline 18 & 407.79 & 17 & 641.79 & 19 & 305.08 & & 55 & 354.66 \\
\hline 41 & 701.49 & 36 & 810.77 & 41 & 170.39 & & 119 & 682.65 \\
\hline 35 & 786.00 & 42 & 716.10 & 57 & 335.64 & & 135 & 837.74 \\
\hline & - & & 835.20 & 12 & 114.26 & & 12 & 949.46 \\
\hline 3 & 119.39 & & 808.71 & & 204.32 & & 5 & 132.42 \\
\hline 477 & 926.57 & 470 & 569.01 & 568 & 659.67 & 1 & 517 & 155.25 \\
\hline
\end{tabular}

\section{EXPENDITURE}

1. Administration

2. ICSU Contribution

3. Commission Expenses

4. Commission Projects 4.1. Exchange 4.2. Teaching 4.3. Other

5. General Assembly

6. IAU Publications

7. Dev. Count. + EC

8. EC Meetings

9. Officers' Meetings

10. Symposia \& Colloquia

11. Inter-Unions Comm.

12. E.C. Projects

13. Representation

14. Bank Charges

15. Young Ast. Schools

16. Regional Meetings

17. SNC

18. Misce11aneous

$$
\begin{aligned}
& \begin{array}{llllll}
165 & 659.46 & 160 & 411.70 & 161 & 631.26
\end{array} \\
& \begin{array}{llllll}
7724.00 & 9817.86 & 9 & 268.91
\end{array} \\
& \begin{array}{l}
-\quad 7014.50 \quad 15353.75 \\
\hline
\end{array} \\
& \begin{array}{llll}
8468.11 & 15 & 754.67
\end{array} \\
& 3622.50 \quad 2010.27 \\
& \begin{array}{lll}
6 & 237.75
\end{array} \\
& 6 \quad 685.24 \\
& 30 \quad 889.38 \\
& 10200.84 \\
& 7047.68 \\
& 151825.24 \\
& 16 \quad 827.19 \\
& 53736.94 \\
& 25361.27 \\
& 2466.04 \\
& 6866.11 \\
& 19330.04 \\
& 5031.29 \\
& 32933.93 \\
& 37841.04 \\
& 7134.35 \\
& 4747.46 \\
& 13420.70 \\
& 52954.71 \\
& 85119.46 \\
& 79 \quad 218.67 \\
& 7333.12 \\
& 8397.15 \\
& 8439.71 \\
& 11148.00 \\
& 4678.28 \\
& 7384.95 \\
& 3422.91 \\
& 2901.80 \\
& 14 \quad 172.08 \\
& 1199.24 \\
& 1020.78 \\
& 1467.27 \\
& 2737.00 \\
& 20 \quad 881.52 \\
& 1006.25 \\
& 20 \quad 000.00 \\
& \text { - } \\
& 763.51 \\
& 3537.05 \\
& 39560.33 \\
& 412.30 \\
& 370.76 \\
& 484730.84 \\
& \overline{441435.96} \\
& 457279.53 \\
& 487 \quad 702.42 \\
& 26 \quad 810.77 \\
& 22368.25
\end{aligned}
$$$$
\underline{29 \quad 133.05 \quad 111 \quad 380.14}
$$

$=6804.27 \quad \underline{29} \quad 133.05 \quad 111 \quad 380.14 \quad \underline{133 \quad 708.92}$

BALANCE 


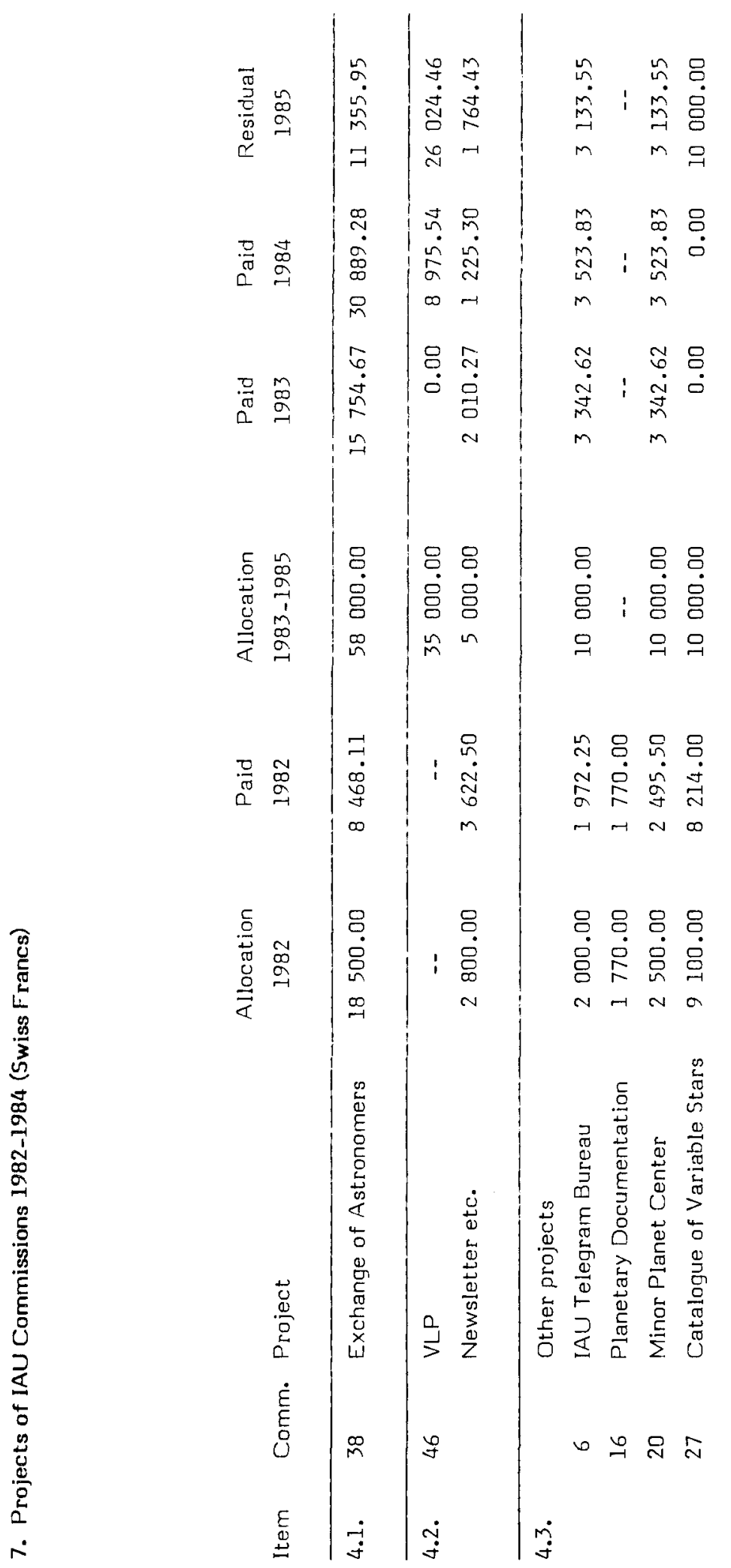




\section{1985 Residual and Proposed Budget (Swiss Francs)}

Residual

EC Proposed

\section{RECEIPTS}

1. Contributions

378714

379000

2. Publications

14054

17000

3. Interest

47019

32000

4. UNESCO/ICSU

$-32052$

50000

5. Miscellaneous

$-12949$

0

394786

478000

Excess of Payments over Receipts

140200

$141 \quad 100$

534986

618100

\section{PAYMENTS}

1.1. Administration

177958

158000

1.2. Secretarial i-telp

10000

6000

2. ICSU Contribution

10613

11000

3. Commission Expenses

$-7369$

15600

4. Commission Projects

55412

55000

5. General Assembly

$183 \quad 173$

213000

6. IAU Publications

15309

23000

7. Developing Countries \& EC

8103

10000

8. ECMeetings

$-775$

0

9. Officers' Meetings

1832

7000

10. Symposia and Colloquia

60662

95000

11. Inter-Unions Comm.

26925

15000

12. EC Projects

$-4533$

1000

13. Representation

12926

7000

14. Bank Charges

1488

1500

15. Young Astronomers' Schools

15118

0

16. Regional Meetings

$-29560$

0

17. SNC

4588

0

18. Miscellaneous

$-3908$

0 

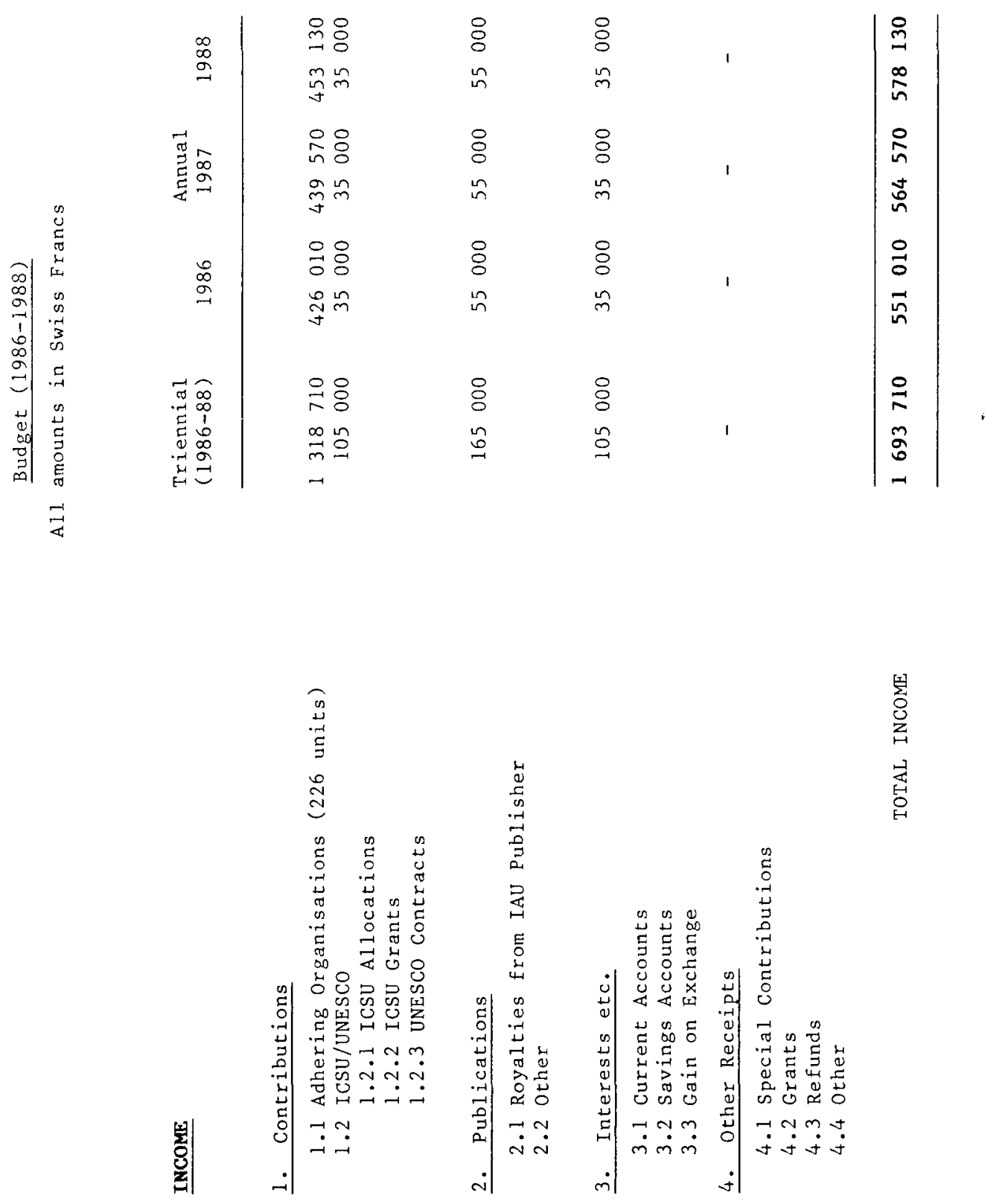


\begin{tabular}{|c|c|c|c|c|c|c|}
\hline $\begin{array}{l}\infty \\
\infty \\
\stackrel{-}{二}\end{array}$ & $\begin{array}{l}8 \\
8 \\
\infty\end{array}$ & $\begin{array}{l}8 \\
8 \\
\infty\end{array}$ & $\begin{array}{ll}8 & 8 \\
8 & 8 \\
2 & 1\end{array}$ & $\begin{array}{l}8 \\
8 \\
\text { ㄱ }\end{array}$ & 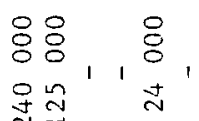 & $\begin{array}{l}8 \\
8 \\
\infty \\
\infty\end{array}$ \\
\hline 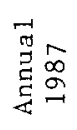 & $\begin{array}{l}98 \\
98 \\
0\end{array}$ & $\begin{array}{l}8 \\
8 \\
\text { in }\end{array}$ & $\begin{array}{l}8 \\
8 \\
0 \\
\pm \\
-1\end{array}$ & $\begin{array}{l}8 \\
8 \\
0 \\
2\end{array}$ & 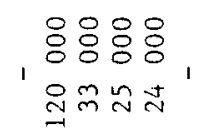 & $\begin{array}{l}8 \\
8 \\
0 \\
\text { ป } \\
\text { N }\end{array}$ \\
\hline $\begin{array}{l}0 \\
\infty \\
\stackrel{-}{-}\end{array}$ & $\begin{array}{l}88 \\
8 \\
8 \\
8 \\
8\end{array}$ & $\begin{array}{l}8 \\
8 \\
\infty \\
y\end{array}$ & $\begin{array}{ll}8 & 8 \\
8 & 8 \\
2 & =\end{array}$ & $\begin{array}{l}8 \\
8 \\
2\end{array}$ & 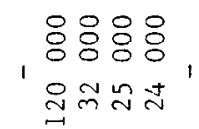 & $\begin{array}{l}8 \\
8 \\
\overrightarrow{0}\end{array}$ \\
\hline 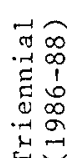 & $\begin{array}{l}888 \\
888 \\
\infty \mathbb{N}^{\circ}\end{array}$ & $\begin{array}{l}8 \\
8 \\
8 \\
0\end{array}$ & 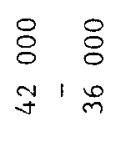 & $\begin{array}{l}8 \\
8 \\
\infty \\
\sim\end{array}$ & 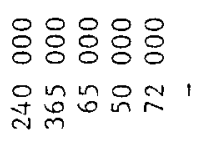 & 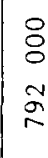 \\
\hline
\end{tabular}
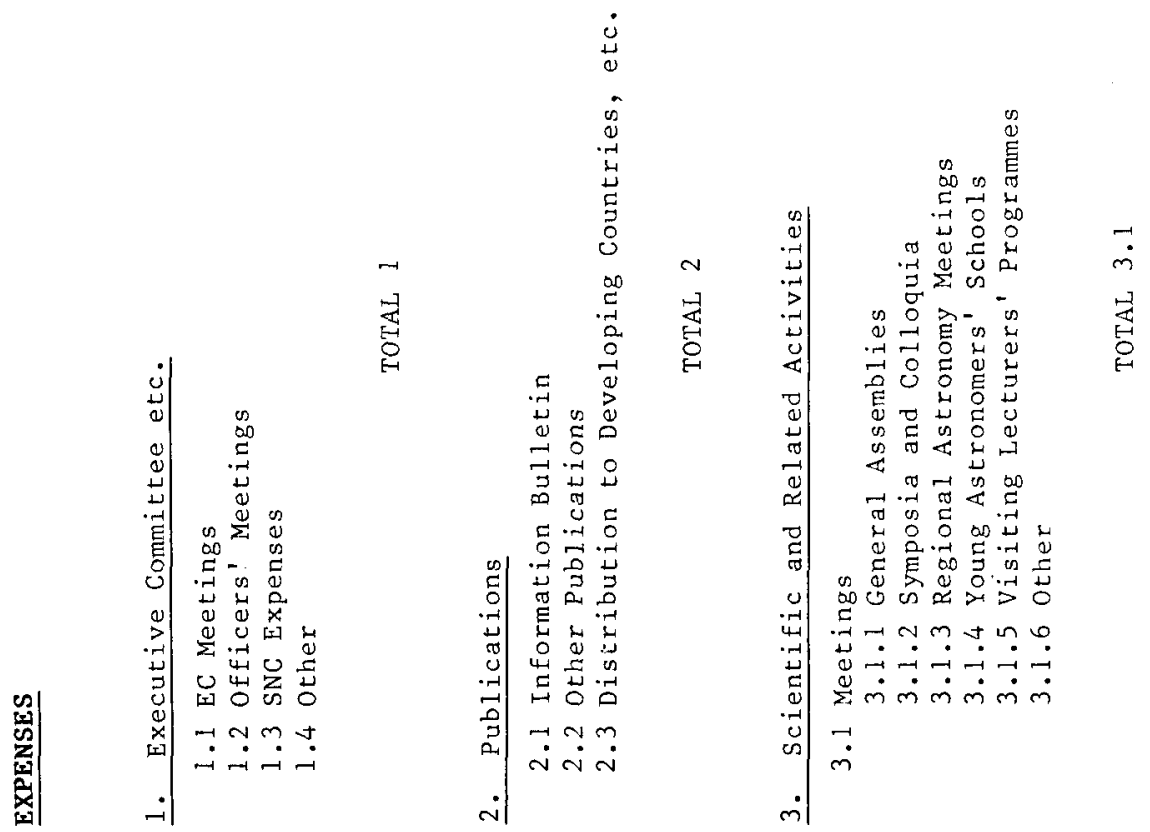


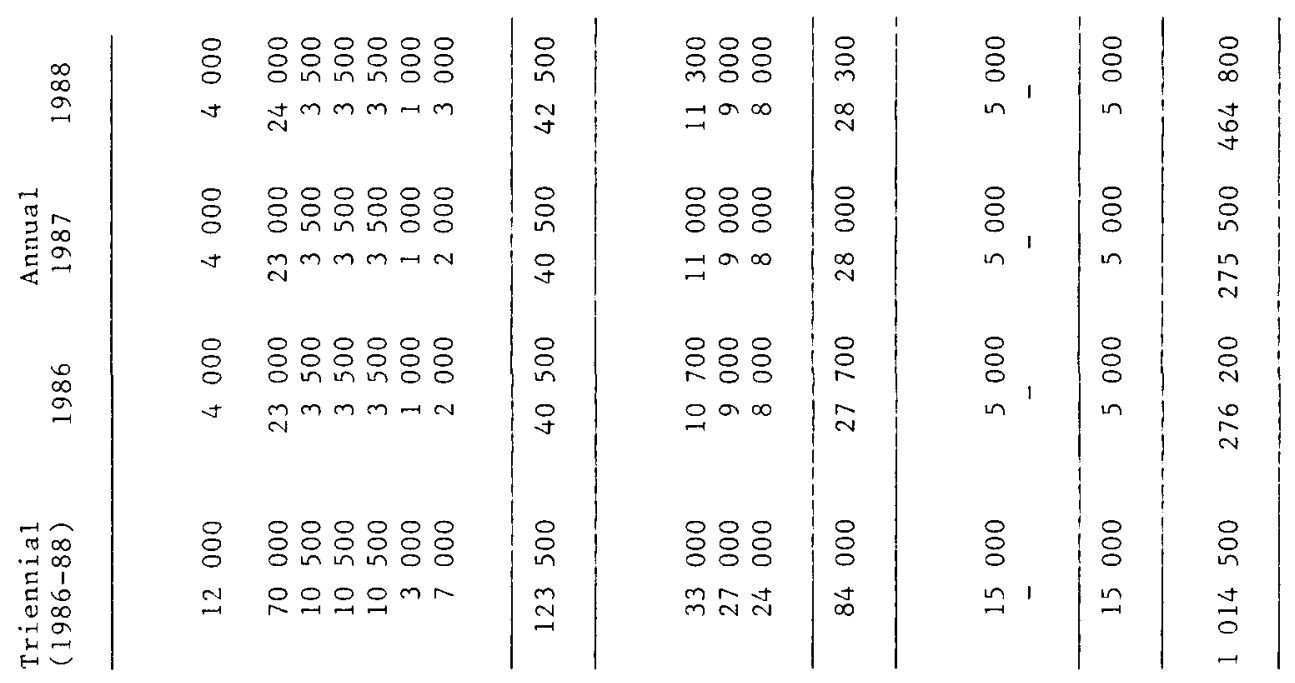
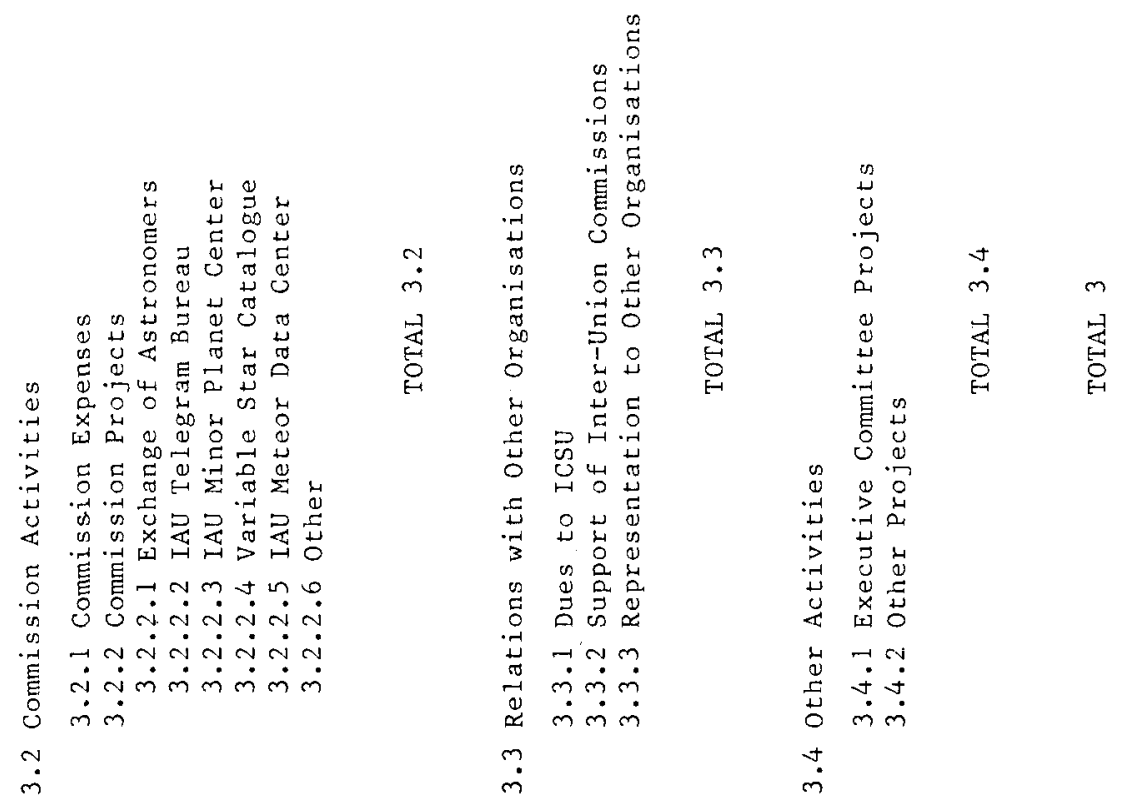

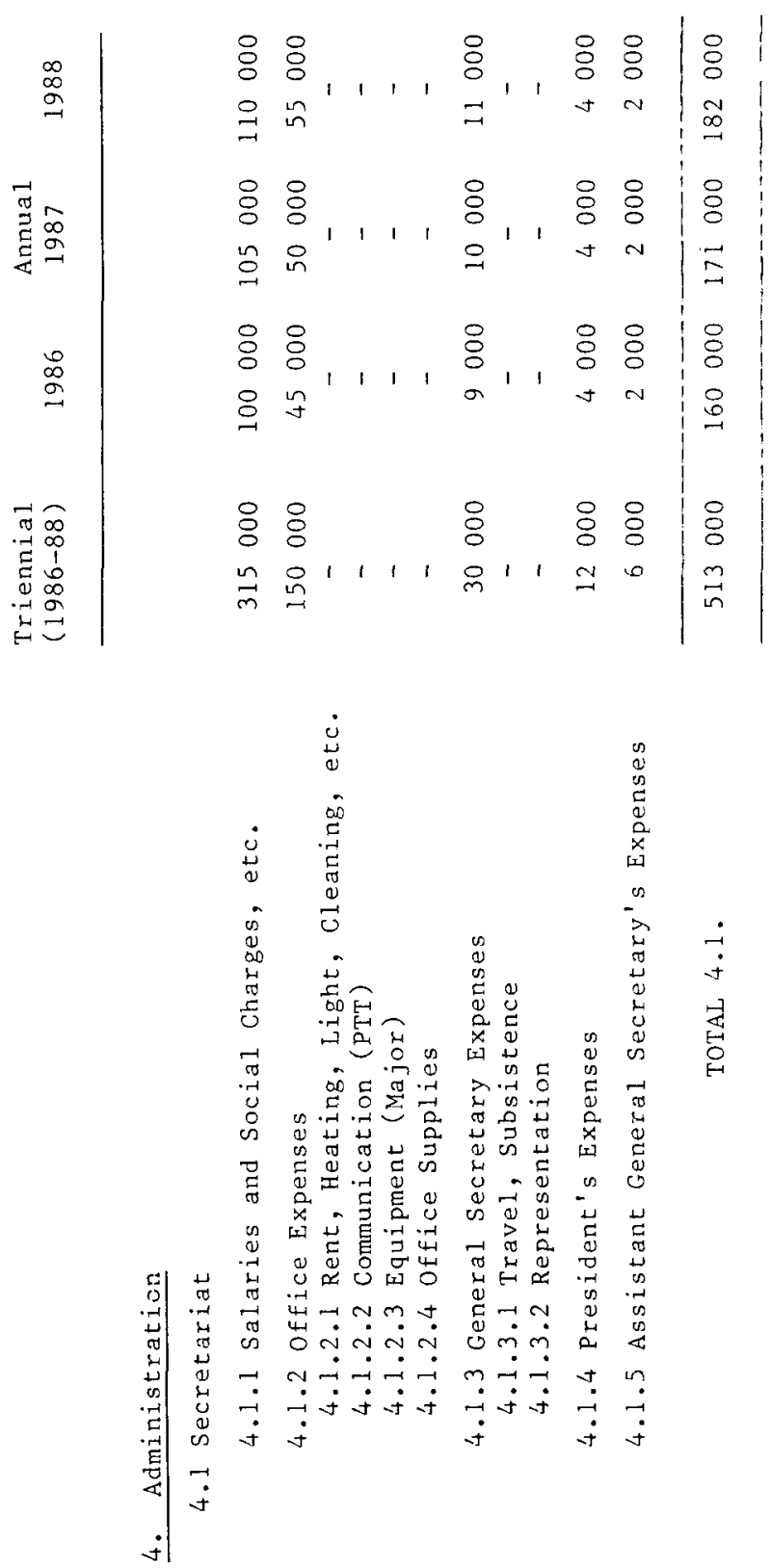


\begin{tabular}{|c|c|c|c|c|c|c|c|}
\hline $\begin{array}{l}\infty \\
\infty \\
\stackrel{2}{\Omega}\end{array}$ & $\begin{array}{l}8 \\
8 \\
-1\end{array}$ & $\begin{array}{l}8 \\
\text { in } \\
-1\end{array}$ & 1 & 1 & $\begin{array}{l}8 \\
\text { in } \\
\text { N }\end{array}$ & $\begin{array}{l}\stackrel{8}{0} \\
\text { 足 } \\
+\end{array}$ & $\begin{array}{l}8 \\
\text { D } \\
\infty\end{array}$ \\
\hline 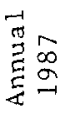 & $\begin{array}{l}8 \\
8 \\
-1\end{array}$ & $\begin{array}{l}8 \\
\text { 足 } \\
-1\end{array}$ & I & 1 & $\begin{array}{l}8 \\
\text { in } \\
\text { N }\end{array}$ & 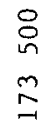 & \begin{tabular}{l}
8 \\
8 \\
$\infty$ \\
\multirow{N}{N}{}
\end{tabular} \\
\hline $\begin{array}{l}0 \\
\infty \\
\stackrel{2}{-1}\end{array}$ & $\begin{array}{l}8 \\
8 \\
-1\end{array}$ & $\begin{array}{l}8 \\
\text { in } \\
-\end{array}$ & 1 & 1 & $\begin{array}{l}8 \\
\text { in } \\
\text { iv }\end{array}$ & 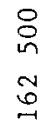 & $\begin{array}{l}8 \\
\stackrel{0}{0} \\
\text { 웅 }\end{array}$ \\
\hline 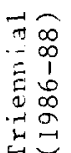 & $\begin{array}{l}8 \\
8 \\
m\end{array}$ & $\begin{array}{l}8 \\
\text { in } \\
\text { t }\end{array}$ & 1 & 1 & $\begin{array}{l}8 \\
8 \\
n \\
n\end{array}$ & 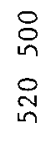 & \begin{tabular}{l}
8 \\
8 \\
\multirow{N}{*}{}
\end{tabular} \\
\hline
\end{tabular}

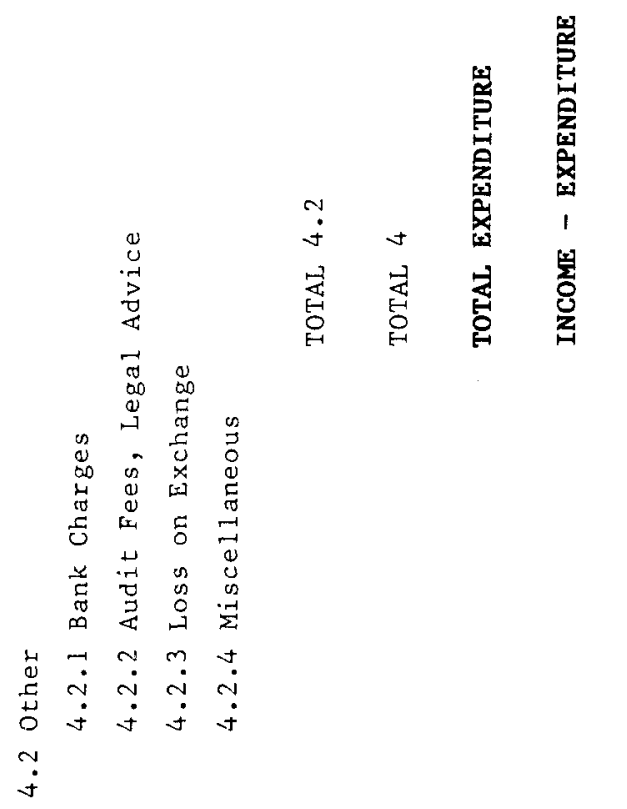

